\title{
1. INTRODUCTION AND SUMMARY OF RESULTS, DEEP SEA DRILLING PROJECT LEG 50
}

\author{
Yves Lancelot, Département de Géologie Dynamique, Université Pierre et Marie Curie, Paris, France, and \\ Geological Research Division, Scripps Institution of Oceanography, La Jolla, California \\ and \\ Edward L. Winterer, Geological Research Division, Scripps Institution of Oceanography, La Jolla, California
}

\section{INTRODUCTION}

Our knowledge of the earliest stages in the evolution of the Atlantic Ocean remains very limited. Although much progress has been made by studying the geological record of sedimentary basins from various Atlantic margins and by drilling in the deep ocean, the oldest part of the record is still unknown. Recent Glomar Challenger cruises in the Central and North Atlantic, including DSDP Leg 50, have added substantial information bearing on our still-schematic views on the evolution of rifted margins. Although drilling into the deep oceanic basins at sites as close as possible to the foot of a margin is a direct and powerful method to study the early history of margins, this approach is difficult because the most interesting targets are generally beneath the thick sediments of continental rises.

In the search for target areas where the Glomar Challenger drill could reach very old strata, the eastern Atlantic margins have long been considered particularly attractive, because unlike their western counterparts that are buried by a thick wedge of Tertiary hemipelagic rise sediments they are characterized by poorly developed continental rises.

The margin off Morocco is one of these "starved" margins and has many features that make it especially suitable for study by deep drilling. Since it is among the oldest "starved" passive margins of the Atlantic - and hence of the world - we can here address both the Jurassic history of the ocean and the fundamental questions of the evolution of passive margins. Drilling into the Moroccan Basin on Leg 50 aimed at filling a specific gap in our understanding of the pre-Oxfordian history of both the Atlantic and the world ocean.

The Moroccan Basin is limited on the west by the lower reaches of the Mid-Atlantic Ridge and by the Madeira Rise, on the north and northeast by the AzoresGibraltar zone of seismic activity and the pile of Tertiary nappes skirting the Rif chain, on the east by the Moroccan part of the African continental margin, and on the south by the westward extension of the Atlas belt and the volcanic complex of the Canary Islands.

The basin presents the classical structure characteristic of an oceanic basin created by rifting and drifting after the separation of the American and African continental masses. Seismic profiles show that sediment thickness increases toward the margin. The oceanic basement can be traced eastward nearly to the base of the continental margin. Along the margin, beneath the shelf and the rise (where present), as well as in the deep easternmost part of the basin itself, a relatively large field of diapirs suggests the presence of evaporites that are probably associated with the early phases of opening of the Atlantic.

The age and nature of the basement immediately adjacent to the outer edge of the margin are unknown. It could consist of continental or oceanic crust, or of some kind of transitional or mixed complex. Most of the basin is within the Jurassic magnetically quiet zone, and the magnetic data do not provide crucial information on the petrology or structure of the basement rocks. A major magnetic anomaly (anomaly $\mathrm{J}$ ) at or very close to the quiet-zone boundary may correspond to a linear basement topographic high - possibly accompanied by intrusives - rather than to a field reversal.

West of that major anomaly is a sequence of poorly defined anomalies believed to correlate with the Mesozoic (M-series) anomalies observed south of the Canary Islands (Hayes and Rabinowitz, 1975). If we assume that the basement is oceanic beneath most of the basin, and if we further assume that the magnetically quiet zone is of the same nature and origin both north and south of the Canary Islands, then the crust at the base of the Moroccan margin may be as old as Early Jurassic (possibly 165-175 m.y.). The two sides of the Atlantic show excellent symmetry north and south of the New England-Canary volcanic complexes. The boundary between the M-series and the magnetically quiet zone has been well dated as Oxfordian south of the New England Seamounts in the western Atlantic (Site 105; Hollister, Ewing, et al., 1972) and the Canary Islands in the eastern Atlantic (Site 367; Lancelot, Seibold, et al., 1978).

The oldest strata ever reached in the deep ocean where the basement is oceanic crust are Oxfordian; such sediments were recovered along both the North American and African margins at Sites 100 and 105 during Leg 11 (Hollister, Ewing, et al., 1972), at Site 391 during Leg 44 (Benson, Sheridan, et al., 1978), and at Site 367 during Leg 41 (Lancelot, Seibold, et al., 1978). At all these sites, the sediments are argillaceous reddish limestone, commonly containing abundant aptychi and some ammonite phragmocones. At Sites 100, 105, and 367 , these strata rest directly on oceanic basalts, slightly within the Jurassic magnetically quiet zone. At Site 391, well within the quiet zone, a thick sedimentary section 
lies between the Oxfordian limestone and the basement below, but these rocks could not be sampled, because of technical problems.

South of the Canary Islands, within the quiet zone, there is commonly a major seismic reflector in the lower part of the sedimentary section. This reflector (reflector " $C$ ") terminates toward the west, where it abuts the basement close to the quiet-zone boundary; it therefore is inferred to be Oxfordian. This age has been confirmed in the Cape Verde Basin at Site 367, where the drill reached the reflector. Although correlation of reflectors on both sides of the Canary Islands-Atlas tectonic zone remains uncertain, there is some reason to believe that the prominent reflector ("blue" reflector) observed on seismic profiles from the Moroccan Basin is the equivalent of reflector " $C$," because it also reaches basement in the vicinity of the quiet zone boundary, which probably corresponds to a relatively reliable basement isochron. Therefore the "blue" reflector also has been correlated tentatively with Oxfordian beds in the Moroccan Basin. Thus, a thick pre-Oxfordian section probably is present in the interval between this reflector and the acoustic basement. Furthermore, if the diapiric evaporites that begin at the eastern limit of the deep basin are of an age comparable to that of the adjacent shelf and emergent areas in Morocco, then there is good reason to believe that strata as old as Early to Middle Jurassic are present just seaward of the field of diapirs.

We recognized early in the planning phase that the main objectives were at sub-bottom depths of at least 2500 meters - and that therefore only a single multiplere-entry drill hole should be attempted, and this required a full two-month leg. Such a deep hole had never been drilled by Glomar Challenger, and the plan thus represented a technical challenge which the JOIDES Planning Committee considered a timely test of the capabilities of the vessel, before planning for further exploration of passive margins.

Two alternate sites were selected for this attempt. Both are close to the base of the continental slope, about $30 \mathrm{~km}$ seaward of the field of diapirs, and about $300 \mathrm{~km}$ landward of the Jurassic-quiet-zone boundary. Site selection was based on multichannel profiles made available to us by A. Brown of Geophysical Services International and by $\mathrm{K}$. Hinz of the Bundesanstalt für Geowissenschaften und Rohstoffe (Hannover, Federal Republic of Germany). A line drawing of this profile appears on Figure 1.

The first site (Site 415) is in the southern part of the Moroccan Basin, on the northern flank of the Agadir Canyon, about $160 \mathrm{~km}$ off the coast of Morocco (Figure 2). Because of the proximity of the Canary Island uplift, both the water depth (2794 meters) and the total depth of basement below sea level (approximately 5700 meters) are relatively shallow compared to the rest of the basin, and the basement lies within the limits of the drill string length of Glomar Challenger. One disadvantage of this site, however, is that the "blue" reflector (and therefore the uppermost part of the target strata) lies approximately 2500 meters below the sea floor.

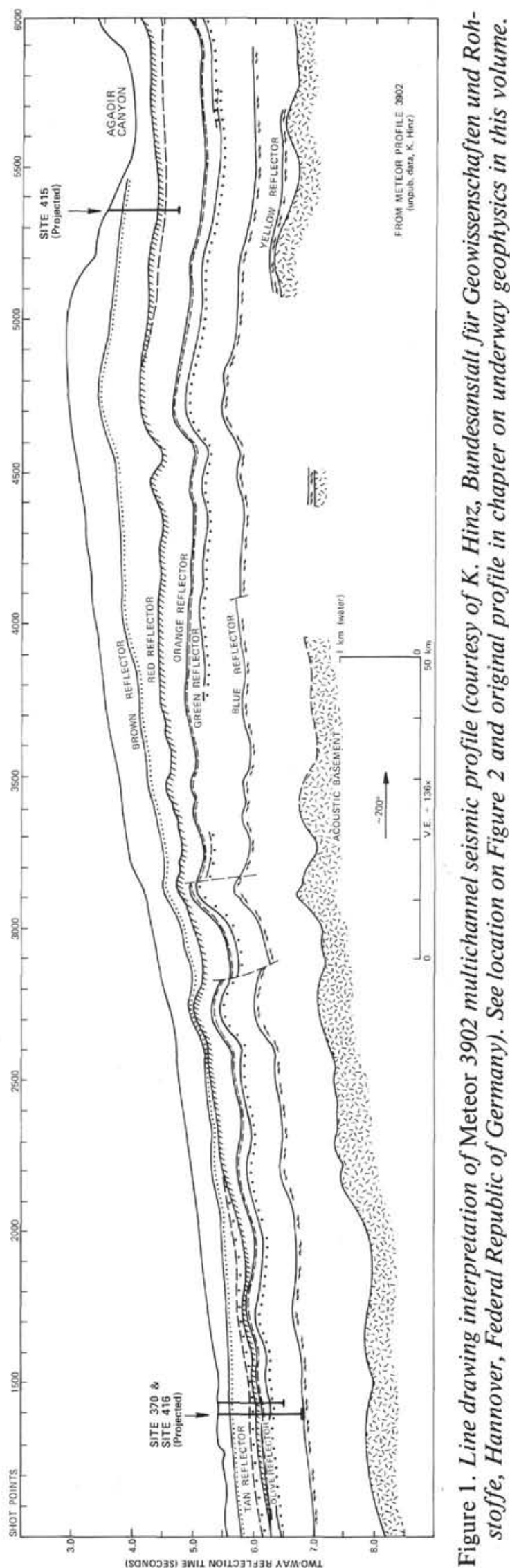




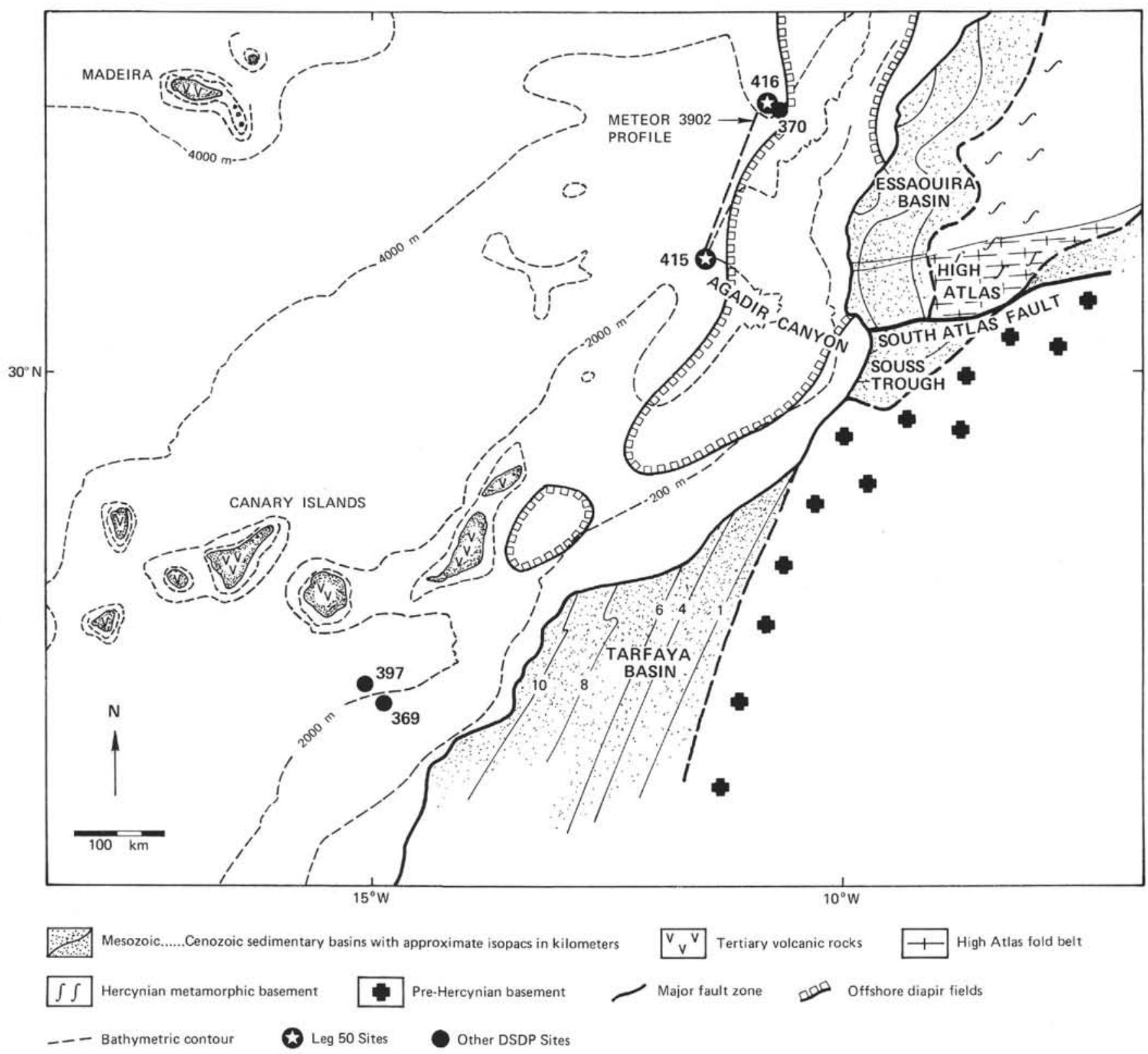

Figure 2. Location of Leg 50 drill sites and major features of the Moroccan Basin and margin.

The second site (Site 416) is in the immediate vicinity of Site 370 (Figure 2), which was drilled during Leg 41 to a depth of 1176.5 meters, where it terminated in Neocomian strata (Lancelot, Seibold, et al., 1978). This location presented the advantage of a shallower sub-bottom depth for the "blue" reflector (about 1700 meters), but the total depth to basement (about 7500 meters) made it out of reach of the Glomar Challenger. Depth to basement was the most important factor in the decision to begin drilling at the southern site (Site 415).

A detailed cruise narrative can be found in the two site reports in this volume. We will comment here only on the main conditions that limited deep penetration and which blocked us from the most important objectives of Leg 50 .
The JOIDES Planning Committee allocated a full two-month leg for the operations, and ideally this time would have been devoted to only a single site. The conditions that led us to revise our plans and to move to the second site after more than 15 days had been spent on the first site were both technical and geological. First, the re-entry cone probably was not set properly, although we had no way to determine exactly what happened when it was placed on the bottom. Apparently, the cone either had been driven into the uppermost soft sediment layers, or it had been very quickly filled and surrounded by a mound of cuttings, because upon the third re-entry the picture on the sonar screen showed that the rim of the cone was very close to the sea floor. The aggravating geological factor was the instability of 
the lowermost formation reached by the drill. It consisted of highly fractured and brittle rock that caved very easily.

Because the rim of the re-entry cone probably was at or even below the sea floor at that time, after more than 1000 meters of penetration, it became almost impossible to flush out cuttings and cavings that kept tumbling back into the hole as soon as they reached the sea floor. These cuttings and cavings filled part of the annulus and prevented free rotation of drill string, and finally penetration stopped.

This first site was abandoned when it became obvious that we would have to set a new cone to resume normal operations. In light of the time remaining for the cruise, it was clear that we had little chance of reaching any of our deep objectives at this site.

Operations at the second site were more successful, at least during re-entry. The cone was properly set and always clearly visible on the sonar. All nine re-entries went smoothly, except when the sonar tool did not work. The major problems at this site were again attributed to the nature of the formations. Rocks were not only hard, slowing down the rate of penetration, but also very brittle and subject to caving. What limited the total penetration was not time, but the impossibility of continuing drilling and coring in a hole partly filled with cuttings and cavings that could never be flushed out of the hole.

It is probable also that caving increased markedly with time and created large variations in the hole diameter. Reduction of the upward flow of drilling fluid in the oversized intervals must have prevented circulation of large pieces of rock to the sea floor. Therefore, in deep penetration of great thicknesses of terrigenous clastics that characterize the continental rises, it appears essential to have long-casing capabilities. Also, flexibility in the casing program ideally should be such that additional casing could be lowered when needed. This could involve use of larger drill bits in the softer sediments of the upper part of the section, so that long, largediameter conductor casing could be set first. Later, smaller-diameter long sets of casing could be lowered when needed. In the types of formations drilled during Leg 50, a hole cased down to about 1500 meters might have allowed for much deeper penetration. Such a figure may be beyond the capability of Glomar Challenger, but it should be considered for future work with larger drilling vessels.

Such work - where prime scientific objectives lie so deep - sometimes exacts a tremendous toll on men and equipment. This should be considered when planning very deep penetration into the thick sedimentary sections of the continental margins, where coring may become scientifically rewarding only after very long months of routine operation.

Operations progress is summarized in Figure 3.

\section{SUMMARY OF RESULTS}

\section{Site 415: Agadir Canyon (Figure 4)}

The Mesozoic part of the section is primarily marlstone at Site 415. The lithology of the oldest strata and their microfossils indicate deep-water environments, below the carbonate-compensation depth, with occasional influxes of redeposited shallow-water material. In younger strata, this influx of redeposited material changes in both quantity and kind: shallow-water (shelf) microfossils are gradually replaced by material of moderately deep water (slope). Most redeposited fossils finally disappear in the Albian to upper-Cenomanian sediments.

The stratigraphy of the Cretaceous is unusual. The gamma-ray log shows striking repetitions of patterns that suggest at least three and perhaps five repetitions of the middle Cenomanian in fault-bounded slices about 50 to 60 meters thick. Evidence of shearing and smallscale folding is abundant in nearly all cores from this interval. Most of this deformation took place while the sediments were still fairly plastic. A plausible origin for these features is gravitational sliding of a relatively thin sheet of sediments (possibly about 200 meters thick) bounded at its base by a contact between Albian shales and underlying more competent rocks.

Paleogene sediments at Site 415 are separated from middle-Cretaceous strata by a major hiatus. In the uncored interval between dated Paleocene and Cretaceous beds, the gamma-ray log shows a sharp peak in the radioactivity of the sediments, corresponding to a local enrichment in radioactive materials that is plausibly associated with an unconformity at the Cretaceous/Tertiary boundary. The Paleocene sediments consist of mudstones with conspicuous intercalations of nannofossil chalk and limestone. Lower-Eocene sediments were recovered only in a very short $(19-\mathrm{cm})$ core made up mainly of pebbles of porcellanite and cherty sandstone with nannofossil marl and mudstone.

Neogene sediments are separated from the Paleogene by another hiatus; they mainly consist of marl, chalk, and ooze, with relatively abundant siliceous microfossils in the lower part of the interval. Fluctuations in the rates of accumulation (with possibly hiatuses) and variations in the preservation of calcareous microfossils suggest shoaling of the CCD during the middle Miocene and near the Miocene/Pliocene boundary.

\section{Site 416: Deep Moroccan Basin (Figure 5)}

Penetration reached 1624 meters at this site - still above the level of our main objective. The hole terminated in Upper Jurassic (Kimmeridgian-Tithonian) sediments that probably lie just above the "blue" reflector. These sediments are distal turbidites of a dual nature. Most of the graded sequences are terrigenous clastic rocks such as quartzose sandstone, siltstone, and mudstone, but about a third of the sequence is redeposited calcareous material which originated on the continental shelf and slope, including calpionellid-rich micrites. Truly pelagic intervals between turbidite sequences are almost invisible, and bioturbation is rare. On the other hand, the microfauna - the benthic foraminifers in particular - indicate that perennial deep-water sediments were present, but that much of this material was redeposited by turbidity currents. The environment of deposition was the lowermost continental rise, near the 
SEPTEMBER 1976

LEG 50 PROGRESS - SITES $415 \& 416$

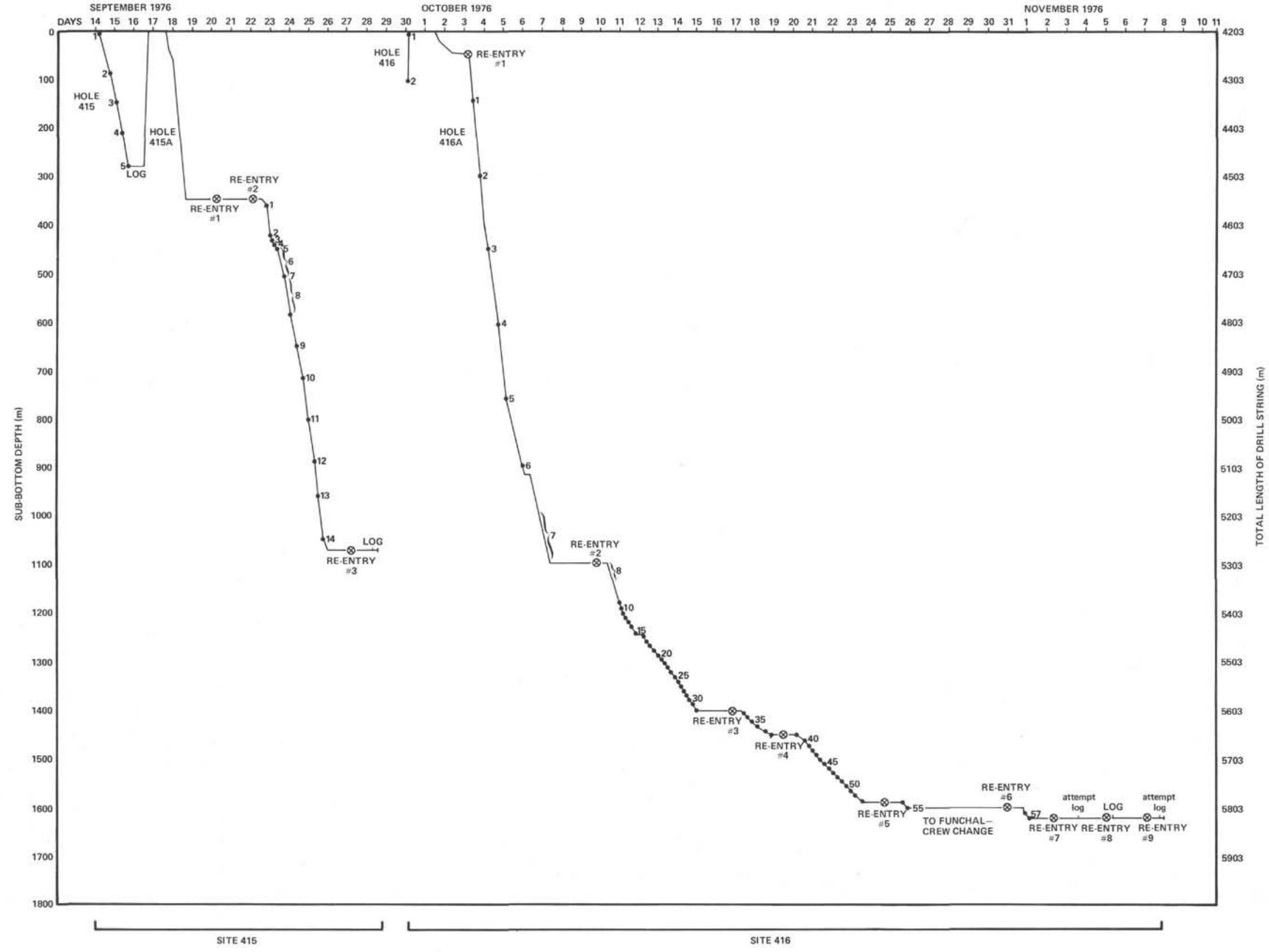




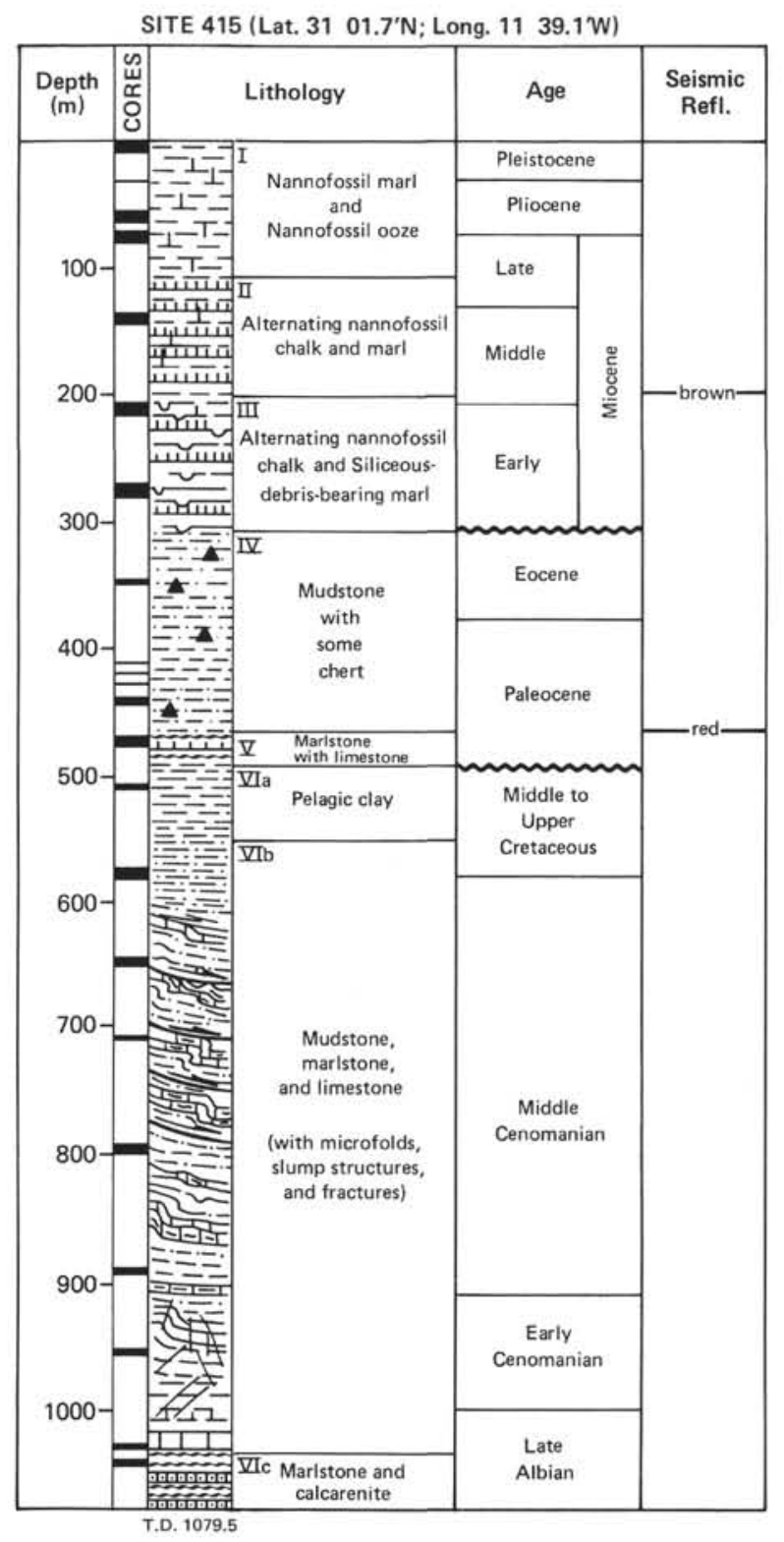

Figure 4. Summary of drilling results at Site 415.

transition plain - an environment comparable to that we see there today.

The same environment prevailed during the earliest Cretaceous - that is, during Berriasian and earlyValanginian times. By the late Valanginian, the turbidites reflect more-proximal conditions, although they still remain generally distal. Carbonate decreased drastically, and the terrigenous facies became predominant. The Hauterivian is characterized by a relatively thick terrigenous flysch that accumulated at a rate of 65 $\mathrm{m} / \mathrm{m} . \mathrm{y}$.

Toward the end of the Hauterivian, the frequency of turbidity currents carrying terrigenous sand, silt, and mud to the base of the continental rise decreased abruptly. Hemipelagic shale and claystone make up most of the Barremian through Albian.
SITES 416 and 370 (Lat. $3250.2^{\prime} \mathrm{N}$; Long. 1048.1 W)

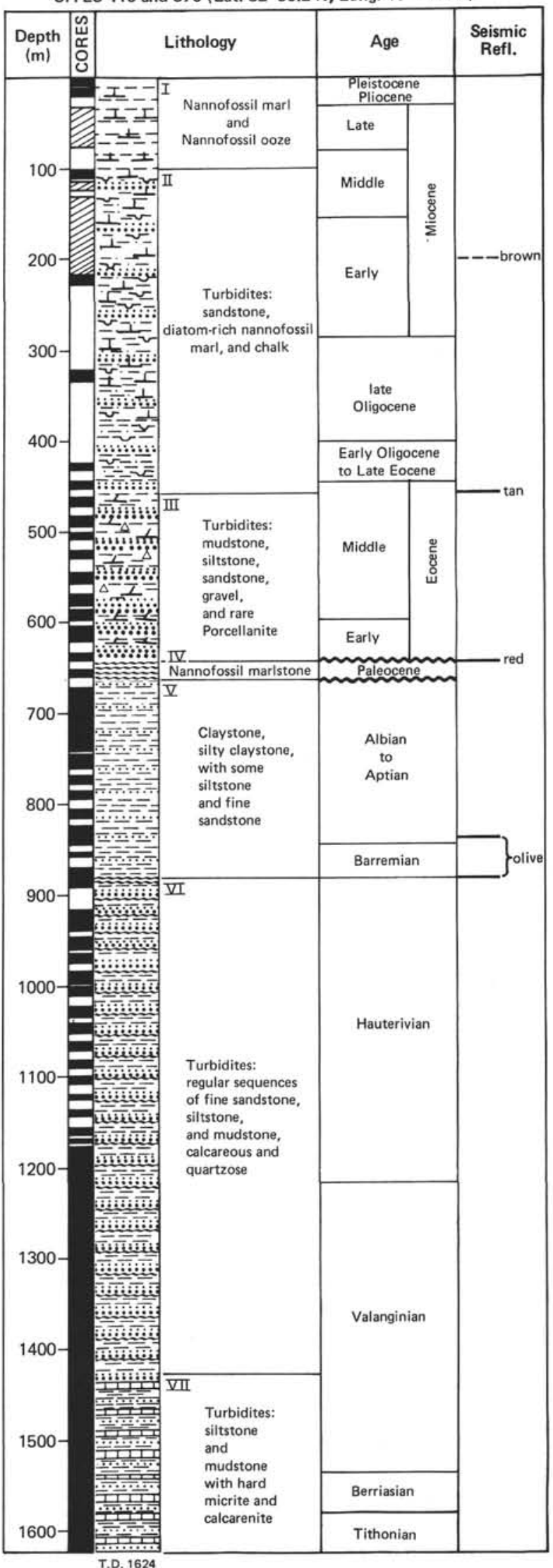

Figure 5. Summary of drilling results at Site 416. 
Post-Albian Cretaceous sediments are not present at Site 416 , probably because of erosion in post-Cenomanian, pre-Cenozoic times. Seismic-profiler data show an erosional unconformity at the "red" reflector, younger and younger beds appearing beneath the unconformity both south and east of Site 416 . The slumped and displaced beds drilled at Site 415 in the Cenomanian are missing at Site 416.

Cenozoic sedimentation began very slowly in the late Paleocene; about $1 \mathrm{~m} / \mathrm{m}$.y. of calcareous clay and marl were deposited over the unconformity. These sediments are probably pelagic, and record an environment a little above the CCD.

A small hiatus in accumulation at the Paleocene/Eocene boundary marks a large change in depositional facies. During the early Eocene and most of the middle Eocene, this part of the lower continental rise was supplied with relatively coarse clastics, including gravels, brought down by turbidity currents. Porcellanite nodules and rare radiolarians suggest that during the Eocene relatively fertile waters overlay the site for the first time since at least the Late Jurassic.

Near the close of the late Eocene, the grain size of the material arriving at Site 370/416 decreased, and sandsilt-marl/mud-turbidite sequences replace the coarsegrained sequences below.

The same distal-turbidite regime prevailed until about the end of the middle Miocene, but stratigraphic control is poor at the top of the sequence because of the wide spacing and uncertain placement of cores.

About 100 meters below the sea floor, probably at a level near the middle/upper Miocene contact, the turbidites give way to nannofossil marl and ooze deposited between the lysocline and the CCD. This facies prevailed until sometime during the late Pliocene. The top of the stratigraphic column is a thin $(0.5-\mathrm{m})$ layer of upper-Pleistocene nannofossil ooze lying on a hiatus that spans the lower Pleistocene and part of the upper Pliocene.

\section{Seismic Reflectors and Down-Hole Logs}

One of the most satisfying results of the operations at Site 416 was the set of Schlumberger logs, although we were unable to $\log$ the entire depth. In general, seismic reflectors could be picked precisely off the down-hole logs instead of through the usual iterative circling around the most plausible matches of velocity structure and lithologic changes. Two reflectors stand out well on the logs: the " $\tan$ " and the "red," and both of these are at unspecified locations. The "tan" reflector is only 30 meters below a large biostratigraphic hiatus, and the "red" reflector is at a minor hiatus only 20 meters above the biggest hiatus in the column. Without the logs, it is likely that the reflectors would have been placed at the important unconformities.

\section{Maturation of Organic Matter}

What started mainly as a safety and pollution-prevention program for this cruise evolved into a particularly rewarding research project in organic geochemistry. The combination of results from organic-carbon content, gaseous-hydrocarbon composition, and pyrolysis analyses provided excellent means for studying the evolution of the organic matter from its origin to its transformation into hydrocarbons. The results show that essentially all the organic matter buried in the sediments from Jurassic to Pleistocene time was derived from terrigenous plants, mainly higher plants. The concentrations of this material are commonly very low, averaging about 1.2 per cent in the Cenozoic, and 0.8 per cent in the Cretaceous. The trend in the Cretaceous is toward decreasing concentrations with increasing depth. With only trivial exceptions, none of the rocks can be considered good source rocks.

The pyrolysis studies show that the organic matter above a depth of about 1200 meters is still immature, while below, down to a depth of 1624 meters, the rocks are only at the beginning of the mature stage.

Gas concentrations are very low in the uppermost 300 meters, increase to nearly 22 per cent at about 900 meters, drop precipitously to about 0.5 per cent at 1000 meters, and gradually dwindle to 0.1 per cent at 1500 meters. The big change comes at the top of the Cretaceous turbidite section and may be related to the facies change there, but it also corresponds to the base of the gas-hydrate stability zone, calculated from extrapolation of the temperature log.

The gas data also confirm the state of maturation of the organic matter: the proportions of the various measured gases (methane, ethane, propane, butane, and pentane) change steadily down the column, until at about 1200 meters pentane (which is on the threshold of the liquid hydrocarbons) makes its first appearance. Incipient maturation of organic matter begins at approximately 1500 meters below the sea floor.

\section{REFERENCES}

Benson, W. E., Sheridan, R. E., et al., 1978. Initial Reports of the Deep Sea Drilling Project, v. 44: Washington (U.S. Government Printing Office).

Hayes, D. E., and Rabinowitz, P. D., 1975. Mesozoic magnetic lineations and the magnetic quiet zone off Northwest Africa. Earth Planet. Sci. Lett., v. 28, pp. 105-115.

Hollister, C. D., Ewing, J. I., et al., 1972. Initial Reports of the Deep Sea Drilling Project, v. 11: Washington (U.S. Government Printing Office).

Lancelot, Y., Seibold, E., et al., 1978. Initial Reports of the Deep Sea Drilling Project, v. 41: Washington (U.S. Government Printing Office). 